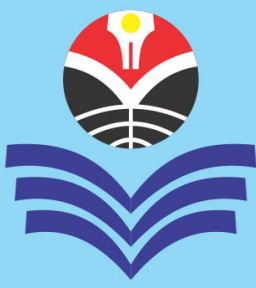

\title{
Dari Sakral Menuju Profan: Pasang-Surut Kesenian Angklung Buncis di Kabupaten Kuningan, Jawa Barat, Tahun 1980-2010
}

\begin{abstract}
ABSTRAKSI: Penelitian ini menjelaskan perkembangan kesenian Angklung Buncis di Kecamatan Cigugur, Kabupaten Kuningan, Jawa Barat, yang memiliki peranan penting dalam upacara Seren Taun yang diadakan oleh masyarakat adat Paseban. Masalah utama yang dibahas adalah bagaimana perkembangan kesenian Angklung Buncis di Kecamatan Cigugur, Kabupaten Kuningan, pada tahun 1980-2010. Metode yang digunakan dalam penelitian ini adalah kualitatif dengan pendekatan studi historis dan budaya. Hasil penelitian menunjukan bahwa kesenian Angklung Buncis di Kecamatan Cigugur, Kabupaten Kuningan berada dalam lingkup masyarakat adat Paseban dan lahir melalui ide kreatif sesepuh adat, yaitu Pangeran Djatikusumah. Terdapat perkembangan fungsi dalam kesenian tradisional Angklung Buncis, yakni dari fungsi sakral berubah menjadi hiburan dan profan. Perkembangan fungsi tersebut terjadi karena permalasahan yang terdapat dalam lingkup masyarakat adat Paseban dan tuntutan zaman. Selain itu, ada perubahan dalam aspek penampilan, lagu, jumlah pemain, dan laras dalam kesenian Angklung Buncis, dengan tujuan untuk mempertahankan keberlangsungan kesenian tradisional tersebut di tengah-tengah perkembangan teknologi yang semakin maju.

KATA KUNCI: Angklung Buncis; Masyarakat Cigugur; Agama Djawa-Sunda; Upacara Seren Taun; Tradisi dan Globalisasi.
\end{abstract}

ABSTRACT: "From Sacral to Profan: Ups and Down of Angklung Buncis Art in Kuningan District, West Java, Year 1980-2010". This study describes the development of Angklung Buncis Art in Cigugur Subdistrict, Kuningan District, West Java, Indonesia, which has an important role in "Seren Taun" ceremony which held by indigenous peoples of Paseban. The main issue discussed was how the Angklung Buncis Art can be develop in 1980-2010. The method used in this research is qualitative with historical study and cultural approaches. The results showed that the Angklung Buncis Art in Cigugur, Kuningan are within the scope of indigenous peoples of Paseban and born through creative ideas from Prince Djatikusumah. There are developments in the functions of the traditional arts of Angklung Buncis, namely from sacred function turned into entertainment and profan. The development of these functions occur because contained within the scope of indigenous peoples Paseban and globalization. In addition, there are changing in the aspects of appearance, song, number of players, and the barrel that aims to maintain the continuity of traditional art in the midst of the development of increasingly advanced technology.

KEY WORD: Angklung Buncis; Cigugur Community; Djawa-Sunda Religion; Ritual of Seren Taun; Tradition and Globalization.

About the Authors: Muhammad Adi Saputra adalah Guru Sejarah di SMAN (Sekolah Menengah Atas Negeri) 8 Tangerang, Banten, Indonesia. Rinaldo Adi Pratama adalah juga Guru Sejarah di SMKN (Sekolah Menengah Kejuruan Negeri) 7 Kabupaten Tangerang, Banten, Indonesia. Untuk kepentingan akademik, penulis dapat dihubungi dengan alamat e-mail: madisaputtra25@gmail.com dan rinaldoadi@outlook.com

Suggested Citation: Saputra, Muhammad Adi \& Rinaldo Adi Pratama. (2018). "Dari Sakral Menuju Profan: PasangSurut Kesenian Angklung Buncis di Kabupaten Kuningan, Jawa Barat, Tahun 1980-2010" in MIMBAR PENDIDIKAN: Jurnal Indonesia untuk Kajian Pendidikan, Volume 3(1), March, pp.59-72. Bandung, Indonesia: UPI [Indonesia University of Education] Press, ISSN 2527-3868 (print) and 2503-457X (online).

Article Timeline: Accepted (November 10, 2017); Revised (January 25, 2018); and Published (March 30, 2018). 


\section{PENDAHULUAN}

Bentuk kebudayaan menjadi salah satu ciri khas dari jatidiri suatu bangsa dan merupakan nilai-nilai luhur yang harus dipertahankan dan dilestarikan (Murtopo, 1978; Muhammad, 1987; dan Putra, 2013). Dalam perkembangannya, kesenian merupakan salah satu unsur kebudayaan yang terus mengalami perkembangan dari masa ke masa, baik dalam bentuk, fungsi, maupun penampilannya yang terkandung dalam suatu kesenian. Seperti yang diutarakan oleh Koentjaraningrat (2009) bahwa kebudayaan adalah keseluruhan sistem gagasan, tindakan, dan hasil karya manusia dalam kehidupan masyarakat, yang dijadikan milik diri manusia dengan belajar (Koentjaraningrat, 2009:144).

Kesenian, dalam budaya universal, akan berhubungan dengan adat-istiadat, aktivitas sosial, dan peralatan fisik mengenai seni rupa, seni suara, seni gerak, seni sastra, seni drama, dan sebagainya (Kroeber \& Kluckhohn, 1952; Kim, 2001; dan Koentjaraningrat, 2009:168-169). Hubungan antar kesenian dengan adat-istiadat, biasa disebut dengan kesenian tradisional. Kesenian tradisional terus berkembang untuk mencapai kesenian nasional, yang mengandung nilai-nilai luhur kepribadian bangsa Indonesia yang akan dikagumi dan dihormati oleh bangsa-bangsa lain di dunia (Bastomi, 1998; dan Sedyawati, 2007).

Kesenian tradisional, atau kesenian daerah, diwariskan dan bersifat turuntemurun dari generasi ke generasi di Nusantara, serta akan mengalami perkembangan dari generasi ke generasi. Pada kenyataannya, kesenian tradisional tidaklah mudah dalam mempertahankan keberadaannya serta dihadapkan kepada arus globalisasi yang semakin besar. Dengan adanya arus globalisasi serta kemajuan ilmu pengetahuan dan teknologi komunikasi yang semakin canggih, maka sangat banyak alternatif tawaran hiburan dan informasi yang lebih beragam dan lebih menarik daripada kesenian tradisional yang terkesan kaku dan kuno (Kayam, 1981; Damono, 1997; dan Soedarsono, 2002).

Kesenian tradisional, yang dikenal bersifat ritual dan sakral, mulai tersingkir dan kehilangan fungsinya. Adanya perubahan sosial yang hadir sebagai akibat proses globalisasi dan teknologi komunikasi, maka kesenian tradisional pun secara perlahan mulai mengalami pergeseran ke arah kesenian yang sebelumnya sakral berubah dimensi menjadi hiburan dan profan (Kasim, 1981; Kuntowijoyo, 1987; dan Soedarsono, 2003). Hal ini bukan berarti membuat kesenian tradisional punah begitu saja, masih terdapat beberapa kesenian yang masih menunjukan keberadaannya dan secara kreatif terus berkembang tanpa harus terlindas oleh proses modernisasi dan globalisasi.

Hal tersebut termasuk dalam perkembangan kesenian Angklung Buncis di Kuningan, Jawa Barat, Indonesia, yang banyak mengalami perubahan. Angklung yang berkembang di masyarakat Sunda masih mencerminkan kepercayaan kuno nenek-moyang, berupa kepercayaan animisme, yang diwujudkan dalam berbagai pementasan untuk ritual menghormati "Dewi Sri" dan sangat erat kaitannya dengan mata pencaharian masyarakat Sunda, yaitu bertani dan berladang (Lombard, 2000; Aziz, 2001; Ekadjati, 2002; dan Saputra, 2015). Begitupun di Kuningan, yang memiliki kesenian tradisional yaitu Angklung Buncis, yang dikembangkan oleh masyarakat adat Paseban dan merupakan kesenian warisan nenek-moyang yang masih dilestarikan dan yang menurut mereka selalu akan terus dilestarikan (Kurnia, 2003; Indrawarhana, 2009; dan Saputra, 2015).

Artikel ini, dengan menggunakan metode kualitatif, pendekatan budaya, dan penjelasan deskriptif yang bersifat historis (Koentjaraningrat, 1958; Gottschalk, 1988; Stake, 1995; Kusmayadi, 2000; Sjamsuddin, 2007; dan Pickering ed., 2008), menjelaskan 
tentang pasang-surut kesenian Angklung Buncis di Kuningan, Jawa Barat, Indonesia, dengan mengkaji dua aspek penting, yakni: (1) Agama Jawa-Sunda dan Cikal-Bakal Lahirnya Angklung Buncis; serta (2) Angklung Buncis: Dari Sakral Menuju ke Arah Profan.

\section{HASIL DAN PEMBAHASAN} Agama Jawa-Sunda dan Cikal-Bakal Lahirnya Angklung Buncis. Angklung Buncis di Kuningan, Jawa Barat, Indonesia merupakan kreasi sesepuh adat mayarakat Paseban di Cigugur, yakni Pangeran Djatikusumah, yang memperoleh inspirasi dari kehidupan keseharian masyarakat setempat (Djatikusumah, 1995; dan Saputra, 2015). Angklung merupakan alat musik tradisional dan digunakan pada upacara yang berhubungan dengan Dewi Sri, dan biasa disebut dengan Nyi Pohaci oleh masyarakat Sunda, termasuk masyarakat adat Paseban (Aziz, 2001; Royyani, 2008; dan Herdiani, 2013).

Angklung Buncis ini dahulu digunakan dalam ritual menyimpan padi ke lumbung dan dilakukan setelah panen. Angklung Buncis semakin berkembang seiring dengan berkembangnya ajaran ADS (Agama DjawaSunda), yang dipelopori oleh masyarakat adat Paseban, yang menganut Sunda Wiwitan (Buana, t.th.; MAKUS, 2008; dan Kushendrawati, 2012). Di Kuningan, ajaran agama ini berkembang pesat di Cigugur dan pengaruhnya meluas hingga ke Brebes, Cirebon, Tasikmalaya, Garut, bahkan sampai ke Bogor dan Sukabumi (Buana, t.th.; HAMKA, 1976; MAKUS, 2008; dan Kushendrawati, 2012).

Dalam melihat perkembangan Angklung Buncis di Kabupaten Kuningan tidak dapat terlepas dengan kondisi kehidupan beragama masyarakat Cigugur. Masyarakat Cigugur memiliki hubungan heterogen dan multikultural yang baik, khususnya dari status agama yang dianut oleh masingmasing masyarakatnya (Royyani, 2004;
Hernawan, 2005; dan Saputra, 2015).

Kepercayaan yang berkembang di Kelurahan Cigugur memiliki perbedaan dengan daerah di Kabupaten Kuningan yang lain. ADS berkembang pesat di Cigugur pada tahun 1940-an; tetapi pada tahun 1974, ADS dibubarkan dan warga diharuskan memilih agama yang diakui oleh pemerintah Orde Baru, seperti Islam, Katholik, Protestan, Hindu, dan Buddha (Buana, t.th.; Rasjidi, 1977; dan Rosidin, 2000). Pada kenyataannya, sampai saat ini, terdapat kepercayaan yang berkembang di Cigugur dan masih memiliki pengikut yang cukup banyak.

Kepercayaan ajaran ADS muncul pada tahun 1848, bertempat di daerah Gebang, Cirebon Timur. Pendiri ADS yaitu Pangeran Sadewa Madrais Kusuma Wijaya Ningrat, atau biasa disebut dengan Pangeran Madrais. Pangeran Madrais merupakan anak dari Pangeran Alibassa I, yang merupakan Sultan dari Kesultanan Gebang (Buana, t.th.; Djatikusumah, 1979; dan Rosidin, 2000).

ADS biasa disebut juga dengan sebutan Madraisme, yang merujuk kepada pendirinya yang bernama Madrais (Rosidin, 2000). Agama ini selanjutnya berkembang di wilayah Cigugur, Kabupaten Kuningan. Selain di Kabupaten Kuningan, ajaran ADS tersebar di berbagai daerah di Jawa Barat, seperti Sukabumi, Garut, dan Tasikmalaya, sehingga pengikutnya banyak tersebar luas di berbagai daerah di Jawa Barat (Buana, t.th.; HAMKA, 1976; Rasjidi, 1977; dan Rosidin, 2000).

Sekitar tahun 1940-an tercatat bahwa anggota pemeluk ajaran ADS mencapai sekitar 60,000 orang. Tetapi dalam perkembangan selanjutnya, ajaran ADS tersebut dibubarkan karena dianggap melawan pemerintah kolonial Belanda (Buana, t.th.; Rosidin, 2000; dan Nurfatwa, 2014). Selanjutnya, di tahun 1970 -an, sebagian besar pemeluk ADS berlindung ke dalam gereja Katholik. Ajaran ADS terus mengalami pasang-surut pada saat Indonesia 
merdeka, sejak tahun 1945, hingga masa pemerintahan Orde Baru, 1966-1998 (HAMKA, 1976; Rasjidi, 1977; dan Indrawardana et al., 2013:37-38).

Sebutan "Djawa" dan "Sunda", dalam ADS, tidak ada kaitannya sama sekali dengan suatu identitas etnis Jawa dan Sunda. Semboyan utama dari ajaran ADS adalah "Andjawat lan Andjawab Roh Susun-susun Kang den Tunda". Dengan semboyan tersebut, kata "Djawa-Sunda" dapat dijelaskan sebagai berikut. Kata "Djawa" adalah singkatan dari andjawat (mengambil) dan andjawab (menjawab atau melaksanakan). Sementara itu, kata "Sunda" adalah singkatan dari kata-kata Roh Susunsusun Kang den Tunda, yang berarti roh yang tersusun-susun tertunda atau yang ada di dunia (Buana, t.th.; Djatikusumah, 1979; Rosidin, 2000; dan Hisyam, 2004:137).

Selain terdapat semboyan, terdapat pula asas dan tujuan ajaran ADS, yaitu selalu mengikuti perintah Tuhan dan patuh kepada perikemanusiaan. Ungkapan yang terkenal dari ADS adalah Sampurnaning Hirup, Sajatining Mati (Hidup Sempurna, Mati Sejati). ADS tidak bisa dipisahkan antara Tuhan dan manusia; pengertian dari manusia itu hendaknya jangan hanya hafal dan mengerti dengan tata-krama saja, melainkan juga mengarahkan seluruh perbuatan dan perilakunya kepada perintah Tuhan (Buana, t.th.; Djatikusumah, 1979; dan Rosidin, 2000).

Manusia adalah makhluk yang paling sempurna di antara makhluk lainnya yang diciptakan oleh Allah. Hanya manusia yang memiliki Sir-Rasa-Pikir dan Akal-Budi atau Rasa Rumasa dan Rasa Tumarima, sementara makhluk lainnya seperti binatang dan tumbuh-tumbuhan hanya memiliki naluri. Manusia, dalam konsep ADS, sebagai medium atau perantara yang paling penting. Karena sifat pengarahan kembali kepada asal yang dimiliki oleh hewan atau tumbuhan, maka membutuhkan manusia sebagai perantara (Buana, t.th.;
Djatikusumah, 1979; dan Rosidin, 2000).

ADS berkembang pesat di lingkungan masyarakat adat Paseban, yang tinggal di lingkungan Gedung Paseban Tri Panca Tunggal. Paseban Tri Panca Tunggal memiliki arti Paseban, yang berasal dari kata Pasebaan, yaitu tempat bertemu dan berkumpul; Tri berasal dari bahasa Sangsekerta yang artinya tiga; dan Panca berasal dari bahasa Sangsekerta juga yang artinya lima; maka Paseban Tri Panca Tunggal yaitu tempat mempersatukan tiga kehendak, yaitu cipta, rasa, dan karsa, yang diwujudkan dalam sikap perilaku melalui aktivitas panca indra (Djatikusumah, 1979; dan Gumilar, 2013:22).

Selain keragaman agama, maka kesenian yang berkembang dalam masyarakat Cigugur di Kabupaten Kuningan, Jawa Barat juga sangat beragam, seperti kesenian tradisional Tari Buyung, Batik Paseban, dan Angklung Buncis. Kesenian yang beraneka ragam tersebut muncul karena kreativitas yang dimiliki oleh masyarakat Kelurahan Cigugur. Khususnya pada upacara Seren Taun, yang mendatangkan banyak wisatawan, sehingga Kelurahan Cigugur semakin dikenal oleh pihak luas (Soedarsono, 1986; Subiantoro, 2002; Gumilar, 2013; dan Herdiani, 2013).

Kesenian di Kelurahan Cigugur sangat beraneka ragam, salah satunya yaitu kesenian tradisional Angklung Buncis, yang merupakan kesenian lama yang telah dimiliki oleh masyarakat Cigugur secara khusus dan masyarakat Kabupaten Kuningan secara umum (Saputra, 2015). Angklung Buncis mengalami berbagai perkembangan yang disebabkan oleh berbagai faktor, khususnya perkembangan zaman yang semakin maju. Kesenian Angklung Buncis telah diakui oleh seniman setempat dan oleh pihak Dinas Pariwisata dan Kebudayaan Kabupaten Kuningan. Kesenian tersebut merupakan salah satu kesenian yang terdapat di Kabupaten Kuningan, meskipun Angklung Buncis tidak 
hanya terdapat di Kabupaten Kuningan, tetapi pada pelaksanaannya di setiap daerah memiliki keunikan yang berbeda, baik dari segi fungsi maupun jenis penampilannya (Saputra, 2015; dan Nuryaman, 2017).

Latar belakang lahirnya kesenian Angklung Buncis di Kabupaten Kuningan, apabila dilihat dari letak geografis Jawa Barat, yang secara umum merupakan pegunungan dan perbukitan serta memiliki tanah yang subur, memberikan kesempatan untuk tumbuh-tumbuhan seperti tanaman kayu keras, tanaman perdu, dan bambu (Ferdinandus, 1999; Masunah et al., 1999; dan Aziz, 2001). Dengan adanya interaksi antara manusia dengan lingkungan menyebabkan munculnya sebuah ide kreatif untuk membuat tumbuh-tumbuhan menjadi nilai yang bermanfaat.

Kesenian Angklung Buncis di Kabupaten Kuningan memiliki cirinya sendiri dan kesenian ini lahir karena sebuah kreasi sesepuh adat, yaitu Pangeran Djatikusumah, yang memperoleh inspirasi dari keseharian masyarakat setempat, yakni masyarakat adat Paseban (Tryana, 2011:2). Kesenian Angklung Buncis tersebut lahir disesuaikan dengan kondisi alam, kondisi lingkungan, dan hal lainnya yang berkaitan dengan suatu kelompok masyarakat. Karena karya seni tradisi pada umumnya dibuat tidak sembarangan dan membutuhkan waktu yang tidak singkat, sebab di balik kesenian tradisi terselip makna, nilai, dan pemikiran dari penciptanya (Herdini et al., 2008:8; dan Saputra, 2015).

Selain faktor tersebut, kesenian Angklung Buncis yang berkembang di Kecamatan Cigugur, Kabupaten Kuningan, Jawa Barat, lahir melalui faktor yang tidak terlepas dari hasil kreativitas masyarakat setempat. Karena adanya bahan yang melimpah dan bertujuan supaya bahan tersebut memiliki sebuah nilai dan fungsi yang bermanfaat, maka diciptakan kesenian Angklung Buncis (Saputra, 2015; dan wawancara dengan Responden B, 20/10/2014). Sebuah kreativitas yang dimiliki oleh masyarakat Cigugur merupakan pemikiran yang disalurkan melalui alam, yang memang memadai dan tersedia.

Kondisi geografis Kelurahan Cigugur di Kabupaten Kuningan, Jawa Barat, yaitu berupa daerah pegunungan karena letaknya terdapat di bawah kaki Gunung Ciremai. Hal ini membuat pohon bambu tumbuh dengan subur, karena disebabkan oleh sisa erupsi Gunung Ciremai yang sangat membantu proses pelapukan tanah (Aziz, 2001; Ekadjati, 2002; dan Saputra, 2015). Dengan adanya hal tersebut, maka muncul ide dari masyarakat setempat untuk membuat tumbuhan bambu memiliki fungsi yang lebih, yaitu dengan cara dibuatnya kesenian Angklung yang berasal dari bahan bambu (Ferdinandus, 1999; Masunah et al., 1999; dan Aziz, 2001).

Alasan lain tentang lahirnya kesenian Angklung Buncis di Kecamatan Cigugur, Kabupaten Kuningan, yaitu ide dari Pangeran Djatikusumah, yang ingin membuat sesuatu kesenian dan memiliki fungsi untuk memeriahkan acara panen, yakni upacara adat Seren Taun, yang sebelumnya terkesan sangat kaku dan menyeramkan (Tryana, 2011; Gumilar, 2013; dan Saputra, 2015). Walaupun hanya untuk memeriahkan upacara adat Seren Taun, tetapi kesenian Angklung Buncis memiliki fungsi yang sangat sakral sebagai media dengan tujuan untuk mengucapkan terima kasih kepada sosok mitologi $N y i$ Pwahaci atau Nyi Pohaci atas hasil bumi melimpah yang diberikan dan tidak terlepas dari ritual-ritual khusus (Subiantoro, 2002; Tryana, 2011; dan Saputra, 2015).

Hal tersebut dipertegas bahwa musik dianggap sebagai sebuah perantara untuk menyatukan antara dunia atas (Tuhan) dengan dunia bawah (manusia). Nilai-nilai yang terdapat dalam musik memiliki suasana magis, yang menurut persepsi kelompok tersebut akan mampu menghadirkan sesuatu yang gaib (cf Subiantoro, 2002; Royyani, 
2004; dan Herdini et al., 2008:5).

Angklung Buncis: Dari Sakral Menuju ke Arah Profan. Angklung Buncis merupakan salah satu kesenian tradisional yang keberadaannya, pada masa-masa awal, kurang diketahui oleh masyarakat luas, khususnya di luar masyarakat adat Paseban (Saputra, 2015). Akan tetapi, di tengah era globalisasi, Angklung Buncis masih dikenal dan digemari oleh masyarakat sekitar, khususnya oleh masyarakat adat Paseban. Angklung Buncis masih dipertahankan dengan upacara ritualnya, karena menjadi bagian penting dalam rangkaian upacara Seren Taun, serta masih memelihara kesenian tradisional tersebut dengan penuh makna dan kekhusyuan di tengah-tengah era globalisasi dan modernisasi (Tryana, 2011).

Dalam upacara Seren Taun, yang digelar setahun sekali, dipertunjukkan kesenian Angklung Buncis oleh masyarakat adat Paseban. Seluruh pertunjukan yang ada dalam upacara Seren Taun itu bersifat sakral dan digunakan sebagai luapan rasa syukur yang ditujukan kepada Tuhan Yang Maha Esa atas limpahan anugrah yang diberikanNya; sedangkan bagi masyarakat umum, upacara ini merupakan tontonan yang bersifat hiburan (Subiantoro, 2002; Royyani, 2008; dan Nuryaman, 2017).

Seren Taun merupakan gelaran budaya tradisional masyarakat agraris Sunda yang masih berada di beberapa daerah di Jawa Barat, dan salah satunya biasa dilaksanakan di Kecamatan Cigugur, Kabupaten Kuningan. Tradisi ini dilaksanakan setahun sekali, yang bertujuan untuk menyerahkan hasil bumi. Secara definisi, Seren Taun diartikan upacara penyerahan hasil panen yang baru mereka lewati serta memohon berkah dan perlindungan kepada Tuhan Yang Maha Esa untuk tahun yang akan datang (Hernawan, 2005; Indrawarhana, 2009; dan Nuryaman, 2017).

Di Kecamatan Cigugur, Kabupaten Kuningan, upacara Seren Taun yang diselenggarakan setiap tanggal 22 Rayagung pada sistem penanggalan Sunda, dipusatkan di Pendopo Paseban Tri Panca Tunggal. Dalam perkembangannya, Angklung Buncis merupakan bagian yang tidak terpisahkan dari upacara Seren Taun, karena ianya merupakan bagian penting dalam prosesi upacara tersebut. Kesenian Angklung Buncis biasanya ditampilkan pada saat upacara itu berlangsung, yang diiringi dengan tariantarian dan kesenian lainnya (Nuryaman, 2017; dan wawancara dengan Responden A, 19/10/2014).

Namun, kini Angklung Buncis terus mengalami perkembangan dan perubahan fungsi, seiring dengan berjalannya waktu. Angklung Buncis yang dahulu berfungsi sebagai sarana upacara yang bersifat sakral, kini berubah menuju ke arah profan (Saputra, 2015). Hal ini diakibatkan karena semakin berkembangnya zaman dan arus globalisasi yang semakin besar. Hal tersebut juga mengubah pandangan dan pemikirian warga masyarakat sekitar, maka fungsi dari Angklung Buncis berubah, selain berfungsi sebagai upacara sakral juga sebagai hiburan (Tryana, 2011).

Dalam hal ini, alasan penulis menggunakan rentang waktu antara 1980 hingga 2010, karena menurut sumber yang didapatkan bahwa kesenian Angklung Buncis pada tahun 1982 tidak ditampilkan dalam upacara Seren Taun. Pada saat itu, upacara Seren Taun ditentang oleh pemerintah Kabupaten Kuningan. Dalam konteks ini, LPKN (Lembaga Pengakajian Kebudayaan Nusantara) menyatakan bahwa gugurnya Seren Tahun di Cigugur merupakan akibat antara ketentuan birokrasi dan kenyataan sadar wisata pada masyarakat luas. Pernyataan tersebut juga sebagai respon atas pembekuan pagelaran upacara Seren Taun sejak tahun 1982. Selama 17 tahun acara tersebut dibekukan, dan baru digelar kembali pada tahun 1999 (Indrawardana et al., 2013:9).

Setelah tahun 2000-an, perkembangan kesenian Angklung Buncis semakin 
diketahui keberadaannya dan dikenal oleh masyarakat secara luas, karena pada tahun tersebut upacara Seren Taun diperbolehkan diselenggarakan kembali oleh pemerintah Kabupaten Kuningan. Angklung Buncis, dalam rentang waktu 1980-2010, mengalami perkembangan dan perubahan fungsi, yakni selain bersifat sakral juga sebagai tontonan dan hiburan yang bersifat profan (Masunah et al., 1999; Rosyadi, 2012; dan Saputra, 2015).

Angklung di Kecamatan Cigugur, Kabupaten Kuningan, Jawa Barat, yang dikembangkan oleh masyarakat adat Paseban disebut "Angklung Buncis", selain karena lagu yang digunakan yaitu lagu Buncis, juga karena kata BUNCIS tersebut memiliki sebuah arti tersendiri, yakni Budaya Urang Nurutkeun Ciri Sunda atau "Budaya Kita Mengikuti Ciri Sunda". Lagu Buncis yang terdapat di Kecamatan Cigugur, Kabupaten Kuningan, Jawa Barat, adalah sebagai berikut:

\section{Cis kacang buncis nyengcle // Di anggo Lati Inem // Nu geulis enca-encle // Jeung aluman- alimeun. \\ [Di sana ada kacang buncis // Dipakai oleh Lati Inem // Wanita cantik berpindah-pindah tempat duduk // Dan nampak malu-malu]. \\ Cis kacang buncis nyengcle // Di anggo Lati Kuda // Nu geulis tembong pingping // Keun wae keur kaula. \\ [Di sana ada kacang buncis // Dipakai oleh Lati Kuda // Wanita cantik kelihatan pahanya // Biar saja buat saya]. ${ }^{1}$}

Kondisi kesenian Angklung Buncis di Kabupaten Kuningan, Jawa Barat, tahun 1980-2010, mengalami perubahan secara dinamis serta berkembang menurut tuntuan zaman yang terus maju. Kesenian tradisional yang hidup di dalam sebuah kelompok manusia dan tinggal di daerah pedesaan akan terus mengalami perubahan dengan tujuan untuk melestarikan kesenian

${ }^{1}$ Lihat, misalnya, Ganjar Kurnia (2003) dan Muhammad Adi Saputra (2015). Terjemahan bebas kedalam bahasa Indonesia dilakukan oleh penulis. tradisional tersebut agar tidak punah digerus oleh zaman (Kayam, 1981; Kuntowijoyo, 1987; dan Soedarsono, 2002 dan 2003). Hal seperti itu juga yang terdapat pada perkembangan kesenian Angklung Buncis.

Angklung Buncis tidak dapat dilepaskan dari fungsi awal dengan kesakralannya, karena ianya merupakan sebuah kesenian yang terdapat dalam rangkaian acara upacara Seren Taun, yang diselenggarakan oleh masyarakat adat Paseban atau masyarakat Cigugur yang menganut kepercayaan Sunda Wiwitan (Buana, t.th.; Nursananingrat, 1964; Hisyam, 2004; Kushendrawati, 2012; dan Sawunggalih, 2012). Angklung Buncis mengalami pergeseran fungsi, dari yang dahulu memiliki sifat sakral, sedangkan saat ini menjadi sebuah hiburan serta perubahanperubahan lain yang terdapat dalam kesenian Angklung Buncis yang memiliki sifat profan (Saputra, 2015).

Banyak faktor yang menyebabkan hal tersebut terjadi, baik faktor internal yang mana masyarakat sudah tidak lagi peduli dengan tradisi leluhurnya; maupun faktor eksternal dengan arus globalisasi semakin besar dan tidak terbendung, sehingga menyebabkan banyak perkembangan dan perubahan. Perkembangan dan perubahan yang terjadi pada Angklung Buncis itu merupakan sebuah keniscayaan yang dimiliki oleh setiap kesenian, karena dilakukan demi keberlangsungan suatu kesenian tradisional tersebut (Kayam, 1981; Tryana, 2011; dan Saputra, 2015).

Pada tahun 1982, terjadi peristiwa penting dalam perjalanan upacara Seren Taun, yang didalamnya termasuk Angklung Buncis. Upacara adat Seren Taun yang diadakan oleh masyarakat adat Paseban, kemudian, menjadi salah satu tempat berkumpulnya wisatawan di Kecamatan Cigugur, Kabupaten Kuningan, yang pernah dibekukan oleh Pemerintah Daerah melalui Surat Keputusan Kepala Kejaksaan Tinggi Jawa Barat, Nomor: Kep.44/K.2.3/8/1982 (dalam Saidi, 2015; dan Saputra, 2015). 
Hal tersebut terjadi karena kecurigaan yang berlebihan terhadap apa yang disebut dengan PACKU (Paguyuban Adat Cara Karuhun Urang atau Perkumpulan Adat Menurut Nenek-Moyang Kita), yang diduga merupakan modifikasi terhadap aliran ADS (Agama Djawa-Sunda). Memang, upacara adat Seren Taun tersebut berasal dari sosok Pangeran Madrais sebagai pendiri ADS (Buana, t.th.; HAMKA, 1976; Rosidin, 2000; Hisyam, 2004; MAKUS, 2008; Kushendrawati, 2012; dan Nurfatwa, 2014). Hal itu juga dipertegas oleh perspektif filsafat dan teori bahwa kebudayaan sangat mempengaruhi sebuah kepercayaan pada masyarakat dan cenderung muncul disintegrasi terhadap sikap eksklusif ideologi, serta turut menyumbang dan memperparah berbagai konflik yang terjadi di tengah-tengah masyarakat (Sutrisno, 2005; Indrawarhana, 2009; dan Alfan, 2013:129).

Setelah peristiwa pembekuan upacara adat Seren Taun itu terjadi, pada tahun 1982, maka kesenian Angklung Buncis ikut mengalami imbasnya, karena tidak lagi dimainkan dalam rangkaian upacara adat tersebut. Angklung Buncis dan kesenian tradisional lain yang terdapat di Paseban Tri Panca Tunggal, yang berfungsi sebagai pendukung dari upacara tersebut, tidak ditampilkan dan hanya melakukan latihanlatihan oleh masyarakat adat Paseban saja selama rentang waktu 17 tahun (19821999), serta tidak boleh ditampilkan di luar lingkungan Paseban Tri Panca Tunggal (Djatikusumah, 1979; dan wawancara dengan Responden A, 19/10/2014).

Pada tahun 1999, setelah upacara Seren Taun diperbolehkan kembali diadakan dan dibuka untuk umum, maka secara keseluruhan kesenian yang terdapat di Paseban Tri Panca Tunggal mendapatkan sebuah kesempatan untuk mempertunjukannya. Hal tersebut mempengaruhi perkembangan kesenian yang terdapat di Paseban Tri Panca Tunggal, termasuk Angklung Buncis. Perkembangan itu membuat Angklung Buncis memiliki fungsi, selain bersifat sakral dan fungsi ritual juga bertambah menjadi fungsi hiburan dan bersifat profan (Kayam, 1981; Tryana, 2011; dan Saputra, 2015).

Angklung Buncis pada tahun 2000-an, selain ditampilkan di acara Seren Taun juga nampak pada pagelaran-pagelaran kesenian di Jakarta atau di Bandung dalam acara pembukaan atau peresmian gedung baru pemerintahan, misalnya. Tetapi dalam acara khitanan atau perkawinan belum pernah tampil, hanya di kalangan pemerintahan saja (wawancara dengan Responden A, 19/10/2014). Hal itu berarti bahwa Angklung Buncis memiliki fungsi ganda, yakni angklung memiliki fungsi awal sebagai sarana upacara ritual padi dan juga saat ini berfungsi sebagai sebuah seni tontonan (Masunah et al., 1999:11; Kurnia, 2003; dan Rosyadi, 2012).

Selain pergeseran dalam bidang fungsi, Angklung Buncis juga mengalami perubahan lainnya. Perubahan tersebut terfokus pada aspek pertunjukan Angklung Buncis, lagu yang dibawakan, penambahan alat yang dipakai, dan perubahan laras atau nada yang digunakan pada saat pertunjukan kesenian Angklung Buncis (Saputra, 2015). Pertunjukan Angklung Buncis, tepatnya mulai tahun 2010, mengalami perubahan yang sangat menonjol, karena kesenian tradisional ini pada pertunjukan dari tahun 1999 hingga 2010, tidak bisa terlepas dari keceriaan atau suka-cita atas berkah yang diberikan oleh Tuhan Yang Maha Esa. Selain itu, kesenian Angklung Buncis memiliki fungsi sebagai media untuk ikut memeriahkan pada setiap acara pertunjukan, khususnya dalam upacara Seren Taun (Hernawan, 2005; Indrawarhana, 2009; dan Nuryaman, 2017).

Tapi pada tahun 2010, pertunjukan Angklung Buncis menjadi lebih diam dan penuh dengan penghayatan. Dalam memainkan Angklung Buncis, misalnya, dilakukan dengan penuh perasaan dan 
tenang, meskipun tidak mengubah nilai terdahulu sebagai simbol luapan rasa syukur terhadap Tuhan Yang Maha Esa. Hal tersebut dipertegas bahwa dalam pertunjukan Angklung Buncis yang dulu bisa diatraksikan dengan gerakan jongkok, duduk, dan tidur, tetapi mulai tahun 2010 tidak lagi dengan gerakan-gerakan seperti itu, tapi dengan penuh penghayatan yang disebut lenyepan (Tryana, 2011; Saputra, 2015; dan wawancara dengan Responden A, 19/10/2014). Lihat dan bandingkan antara gambar 1 dan gambar 2 .

Perubahan yang terjadi pada pertunjukan Angklung Buncis selanjutnya diikuti oleh lagu yang ditampilkan dan laras atau nada yang digunakan. Sebelum tahun 2010, lagu Angklung Buncis diambil dari awal mula lahirnya kesenian tradisional tersebut, yakni dengan judul lagu Buncis. Saat ini, setelah tahun 2010, lagu yang dimainkan dan ditampilkan lebih bervariasi dan banyak. Hal tersebut membuat perubahan laras yang tadinya dikenal dengan salendro (pentatonis rendah) berubah menjadi pelog (pentatonis tinggi). Lagu yang semakin bervariasi menuntut terjadinya perubahan tersebut (Tryana, 2011; dan Saputra, 2015). Hal ini juga dipertegas oleh seorang narasumber, sebagai berikut:

[...] tahun 2010, ada perubahan tangga nada, dulu menggunakan salendro, dan saat ini berubah menjadi pelog, serta perkembangan lagu-lagunya, seperti Karatagan Ciremai, Karatagan Pahlawan, dan Bale Bandung, yang diambil dari pusaka yang ada di dalam

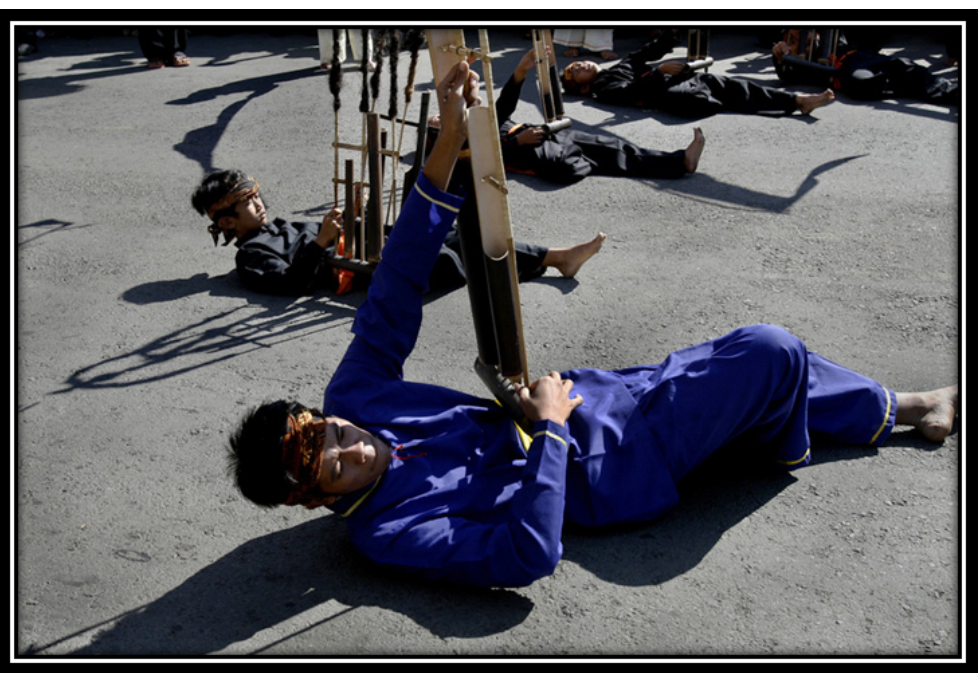

Gambar 1:

"Gerakan Terlentang dalam Penampilan Kesenian Tradisional Angklung Buncis Tahun 2008"

(Sumber: http://4.bp.blogspot.com, 10/11/2014).

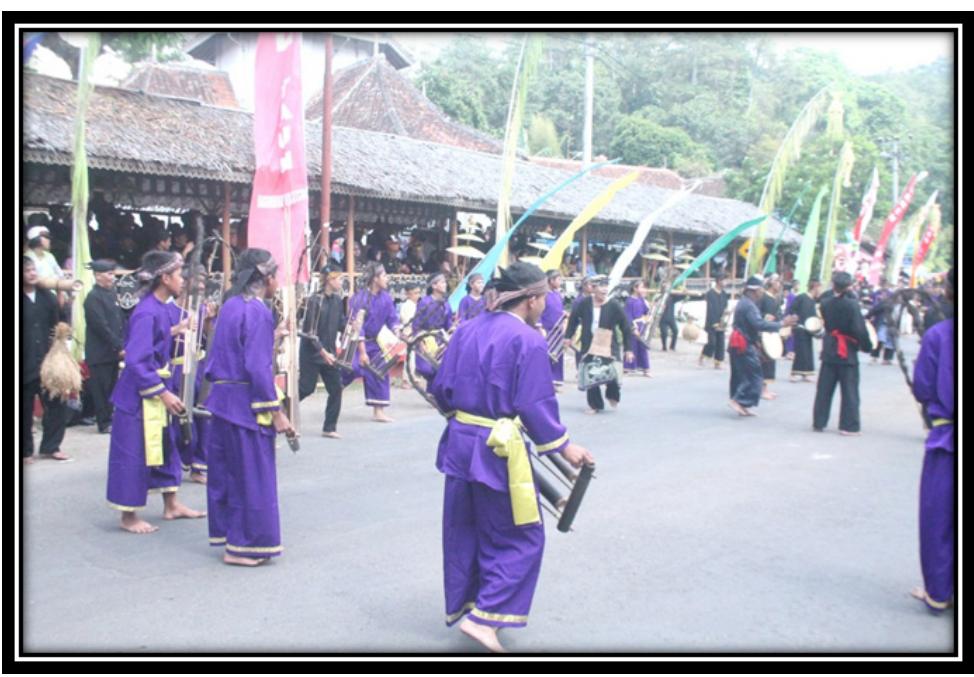

Gambar 2:

"Gerakan Pertunjukan Angklung Buncis dengan Panghayatan Tahun 2010"

(Sumber: Dokumentasi Paseban Tri Panca Tunggal, 10/11/2014) 
Buncis bagi masyarakat adat Paseban. Upaya seniman tersebut dengan melakukan sistem regenerasi kepada generasi muda agar ada penerus dari kesenian Angklung Buncis. Sistem regenerasi adalah dengan cara mengajarkan dan melakukan latihan secara rutin kesenian Angklung Buncis, baik kepada anak-anak yang masih kecil maupun yang sudah dewasa, dengan bersungguhsungguh dan ikhlas dalam mengajarkannya (Sedyawati, 2007; Rosyadi, 2012; dan Saputra, 2015).

Selain itu, usaha yang dilakukan oleh para seniman tidak lepas dari bantuan Pemerintah Daerah, yang terus memberi perhatian dalam hal apapun, khususnya dalam memperkenalkan kesenian Angklung Buncis kepada masyarakat luas, baik di Kabupaten Kuningan maupun di luar daerah tersebut. Pemerintah Daerah, misalnya, memberikan kesempatan kepada seniman Angklung Buncis untuk menampilkan kesenian tersebut dalam acara-acara yang dilaksanakan oleh pemerintah Kabupaten Kuningan, seperti dalam pagelaran budaya yang diselenggarakan oleh Dinas Kebudayaan dan Pariwisata Kabupaten Kuningan (Tryana, 2011; dan Saputra, 2015).

\section{KESIMPULAN}

Angklung Buncis di Kabupaten Kuningan, Jawa Barat, Indonesia, berkembang di lingkungan masyarakat adat Paseban. Kesenian tersebut lahir karena berasal dari ide kreatif sesepuh adat, yaitu Pangeran Djatikusumah, serta tidak terlepas dari hasil kreativitas masyarakat setempat. Letak geografis Kecamatan Cigugur di Kuningan, Jawa Barat, yang berada di lembah Gunung Ciremai membuat tanaman bambu tumbuh dengan suburnya, sehingga kreativitas masyarakat berkembang dan bambu tersebut dibuat menjadi angklung.

Angklung Buncis memiliki peranan penting dalam pertunjukan upacara Seren Taun, karena menjadi salah satu ritual yang ditampilkan dalam rangkaian acara upacara serah-terima padi pada setiap tahun. Upacara adat Seren Taun dikenal dengan upacara yang erat kaitanya dengan hal mistis dan menyeramkan, tetapi alasan lahirnya kesenian Angklung Buncis yaitu agar upacara tersebut bisa lebih meriah dan lebih bersuka-cita. Angklung Buncis ditampilkan pada saat panen raya, tepatnya setiap tangga 22 Rayagung dalam penanggalan masyarakat Sunda, yang bertujuan untuk mengucapkan terima kasih kepada Tuhan Yang Maha Esa, yang telah memberikan hasil bumi yang melimpah.

Angklung Buncis mengalami perkembangan, khususnya pada rentang waktu 1980-2010. Perkembangan tersebut membuat Angklung Buncis mengalami perubahan yang pada awalnya berfungsi sakral dan ritual berubah menjadi sarana hiburan. Sebagai akibatnya, kesenian tersebut memiliki fungsi ganda, yakni selain memiliki fungsi sakral juga fungsi hiburan atau profan.

Perubahan fungsi bermula, ketika terjadi adanya pelarangan dalam menyelenggarakan upacara Seren Taun yang dilaksanakan oleh masyarakat adat Paseban pada tahun 1982 sampai 1999, sehingga membuat seluruh kesenian yang terdapat pada rangkaian upacara Seren Taun, termasuk kesenian Angklung Buncis, menjadi mati suri. Setelah tahun 2000-an, perubahan fungsi telah terjadi pada kesenian tersebut karena memiliki tujuan untuk memperkenalkan kepada masyarakat luas, sehingga kesenian Angklung Buncis ditampilkan dalam acara-acara pemerintahan, pagelaran, dan syukuran dalam tatanan pemerintahan.

Perubahan lain yang terjadi dalam kesenian Angklung Buncis di Kecamatan Cigugur, Kabupaten Kuningan, Jawa Barat adalah perubahan lagu yang dimainkan, penampilan, jumlah pemain, dan laras atau nada yang digunakan. Perubahan yang dilakukan tersebut bertujuan untuk keberlangsungan kesenian Angklung Buncis agar mampu menjawab tuntutan zaman 
yang semakin maju dan masyarakat yang semakin meninggalkan segala sesuatu yang berhubungan dengan ketradisionalannya. ${ }^{2}$

\section{Referensi}

Alfan, M. (2013). Filsafat Kebudayaan. Bandung: Pustaka Setia.

Aziz, Fadhila Arifin. (2001). "Pemanfaatan Bambu dan Relevansinya dengan Nilai-nilai Budaya di Masa Lampau" dalam Mencermati Nilai Budaya Masa Lalu dalam Menatap Masa Depan. Jakarta: Proyek Peningkatan Penelitian Arkeologi.

Bastomi, Suwaji. (1998). Apresiasi Kesenian Tradisional. Semarang: IKIP [Institut Keguruan dan Ilmu Pendidikan] Semarang Press.

Buana, Tedja. (t.th.). Agama Jawa Sunda (Madraisme). Kuningan: Yayasan Tri Mulya.

Damono, Sapardi Djoko. (1997). “Kebudayaan Massa dalam Kebudayaan Indonesia: Sebuah Catatan Kecil" dalam Ecstasy Gaya Hidup: Kebudayaan Pop dalam Masyarakat Komoditas Indonesia. Jakarta: Penerbit Mizan.

Djatikusumah, Pangeran. (1979). Gedung Paseban Tri Panca Tunggal Cigugur, Kuningan. Kuningan: Yayasan Tri Mulya.

Djatikusumah, Pangeran. (1995). Pemaparan Budaya Spiritual Paguyuban Adat Cara Karuhun Urang. Cigugur: t.p. [tanpa penerbit].

Ekadjati, E.S. (2002). Sejarah Kuningan: Dari Masa Prasejarah hingga Terbentuknya Kabupaten. Jakarta: Penerbit Kiblat.

Ferdinandus, Pieter Eduard Johannes. (1999). "Alat-alat Musik Masa Jawa Kuna (Abad IXXV Masehi): Sebuah Kajian mengenai Bentuk dan Fungsi Ansambel”. Disertasi Doktor Tidak Diterbitkan. Yogyakarta: Universitas Gadjah Mada.

"Gerakan Pertunjukan Angklung Buncis dengan Panghayatan Tahun 2010" dalam Dokumentasi Paseban Tri Panca Tunggal, diperoleh penulis pada tanggal 10 November 2014.

"Gerakan Terlentang dalam Penampilan Kesenian Tradisional Angklung Buncis Tahun 2008”.

\footnotetext{
${ }^{2}$ Pernyataan: Kami, dengan ini, menyatakan bahwa artikel ini beserta seluruh isinya adalah benar-benar karya kami sendiri melalui hasil penelitian. Kami tidak melakukan penjiplakan atau pengutipan dengan cara-cara yang tidak dibenarkan dalam etika keilmuan yang berlaku dalam dunia akademik. Kami bersedia menanggung hukuman secara akademik, sekiranya pernyataan yang kami buat ini tidak sesuai dengan kenyataan. Demikian surat pernyataan ini dibuat untuk dipergunakan sebagaimana mestinya.
}

Tersedia secara online di: http://4.bp.blogspot. com [diakses di Tangerang, Banten, Indonesia: 10 November 2014].

Gottschalk, Louis. (1988). Mengerti Sejarah. Jakarta: Penerbit UI [Universitas Indonesia] Press, terjemahan Nugroho Notosusanto.

Gumilar, N. (2013). Seren Taun: Pesona Budaya dan Refleksi Rohani Masyarakat Cigugur. Bogor: Lembaga Pengkajian Kebudayaan Nusantara.

HAMKA [Haji Abdul Malik Karim Amrullah]. (1976). Perkembangan Kebatinan di Indonesia. Jakarta: Penerbit Bulan Bintang.

Herdiani, Een. (2013). “Tari Batik Sekar Galuh: Upaya Pemberdayaan Masyarakat Paseban melalui Aktivitas Seni Budaya Lokal" dalam PANGGUNG: Jurnal Seni \& Budaya, Vol.23, No.2 [Juni]. Tersedia secara online juga di: https://simlitmas.isbi.ac.id/e-jurnal/index.php/ panggung/article/viewFile/98/98 [diakses di Tangerang, Banten, Indonesia: 9 Oktober 2017].

Herdini, H. et al. (2008). Mengungkap Nilai Tradisi pada Seni Pertunjukan Jawa Barat. Bandung: Balai Pengelolaan Kepurbakalaan, Sejarah, dan Nilai Tradisional, Dinas Kebudayaan dan Pariwisata Provinsi Jawa Barat.

Hernawan, Wawan. (2005). "Komunikasi Antarumat Berbeda Agama: Studi Kasus Sikap Sosial dalam Keragaman Beragama di Kecamatan Cigugur, Kabupaten Kuningan, Jawa Barat". Disertasi Doktor Tidak Diterbitkan. Bandung: Program Pascasarjana Ilmu Komunikasi UNPAD [Universitas Padjadjaran].

Hisyam, M. (2004). "Agama Jawa-Sunda" dalam Ibnu Qoyim [ed]. Religi Lokal \& Pandangan Hidup. Jakarta: LIPI [Lembaga Ilmu Pengetahuan Indonesia] Press, hlm.137-173.

Indrawarhana, Ira. (2009). "Komunikasi Budaya Masyarakat Berbeda Keyakinan sebagai Peserta Upacara Adat Seren Taun di Cigugur, Kuningan, Jawa Barat". Tesis Maguster Tidak Diterbitkan. Bandung: Program Pascasarjana Ilmu Komunikasi UNPAD [Universitas Padjadjaran].

Indrawardana, Ira. et al. (2013). Cigugur: Miniatur Pluarlisme Indonesia. Bogor: Lembaga Pengkajian Kebudayaan Nusantara.

Kasim, A. (1981). Ungkapan Beberapa Bentuk Kesenian. Jakarta: Departemen Pendidikan dan Kebudayaan RI [Republik Indonesia].

Kayam, Umar. (1981). Seni, Tradisi, Masyarakat. Jakarta: Sinar Harapan.

Kim, Uichol. (2001). "Culture, Science, and Indigenous Psychologies: An Integrated Analysis" in D. Matsumoto [ed]. Handbook of Culture and Psychology. Oxford: Oxford University Press.

Koentjaraningrat. (1958). Metode-metode Antropologi dalam Penjelidikan-penjelidikan 
Masjarakat dan Kebudajaan di Indonesia: Sebuah Ichtisar. Djakarta: Universitas Indonesia.

Koentjaraningrat. (2009). Pengantar Ilmu Antropologi. Jakarta: Rineka Cipta.

Kroeber, A.L. \& C. Kluckhohn. (1952). Culture: A Critical Review of Concepts and Definitions. Cambridge, MA: Peabody Museum.

Kuntowijoyo. (1987). Budaya dan Masyarakat. Yogyakarta: Tiara Wacana.

Kurnia, Ganjar. (2003). Deskripsi Kesenian Jawa Barat. Bandung: Dinas Kebudayaan \& Pariwisata Jawa Barat.

Kushendrawati, Selu Margaretha. (2012). "Komunitas Agama Djawa-Sunda: Sebuah Fenomena Religiositas Masyarakat di Kuningan, Jawa Barat”. Tersedia secara online di: https://icssis.files.wordpress. com/2012/05/1819072011_29.pdf [diakses di Tangerang, Banten, Indonesia: 9 Oktober 2017].

Kusmayadi, Endar. (2000). Metodologi Penelitian dalam Bidang Kepariwisataan. Jakarta: Gramedia Pustaka Utama.

Lombard, Denys. (2000). Nusa Jawa, Silang Budaya: Batas-batas Pembaratan, Bagian I. Jakarta: PT Gramedia Pustaka Utama, Terjemahan.

MAKUS [Masyarakat Adat Karuhun Urang Sunda]. (2008). Pemaparan Singkat Jejak Sejarah Komunitas ADS (Agama Djawa-Sunda) ke Komunitas AKUR (Adat Karuhun Urang) di Kelurahan Cigugur, Kabupaten Kuningan, Jawa Barat. Cigugur: t.p. [tanpa penerbit].

Masunah, J. et al. (1999). Angklung Jawa Barat: Sebuah Perbandingan. Bandung: CV Andira.

Muhammad, Abdulkadir. (1987). IBD: Ilmu Budaya Dasar. Jakarta: Fajar Agung.

Murtopo, Ali. (1978). Strategi Kebudayaan. Jakarta: Yayasan Proklamasi.

Nurfatwa, Suryana. (2014). “Mengungkap Asal-Usul Agama Sunda Wiwitan”. Tersedia secara online di: http://www.voa-islam.com/read/citizensjurnalism/2014/10/17/33436/mengungkap-asalusul-agama-sunda-wiwitan [diakses di Tangerang, Banten, Indonesia: 9 Oktober 2017].

Nursananingrat, B. (1964). Purwawisada: Agama Djawa-Sunda. Bandung: Pastoral.

Nuryaman. (2017). "Mengenal Seren Taun: Ritual Tahunan Masyarakat Adat Sunda Wiwitan Cigugur". Tersedia secara online di: http://www. pikiran-rakyat.com/jawa-barat/2017/09/14/ mengenal-seren-taun [diakses di Tangerang, banten, Indonesia: 9 Oktober 2017].

Pickering, M. [ed]. (2008). Research Methods for Cultural Studies. Eidenburgh: Eidenburgh University Press.

Putra, H.S. Ahimsa. (2013). "Budaya Bangsa, Jati Diri, dan Integrasi Nasional" dalam Jurnal
Sejarah dan Nilai Budaya.

Rasjidi, H.M. (1977). Islam dan Kebatinan. Jakarta: Penerbit Bulan Bintang.

Rosyadi. (2012). “Angklung: Dari Angklung Tradisional ke Angklung Modern" dalam Patanjala, Vol.4, No.1 [Maret], hlm.25-38.

Rosidin, Didin Nurul. (2000). "Kebatinan, Islam, and the State: The Dissolution of Madrais in 1964". Unpublished Ph.D. Tesis. Leiden: Faculties of Art and Theology, Leiden University.

Royyani, Mohammad Fathi. (2004). "Cigugur: Arena Kontestasi Keberagamaan”. Thesis Magister Tidak Diterbitkan. Depok: Program Studi Antropologi Pascasarjana FISIP UI [Fakultas Ilmu Sosial dan Ilmu Politik, Universitas Indonesia].

Royyani, Mohammad Fathi. (2008). "Upacara Seren Taun di Cigugur, Kabupaten Kuningan, Jawa Barat: Tradisi sebagai Basis Pelestarian Lingkungan" dalam Jurnal Biologi Indonesia, 4(5), hlm.399-415. Tersedia secara online juga di: https://media.neliti.com/media/ publications/78972-ID [diakses di Tangerang, Banten, Indonesia: 9 Oktober 2017].

Saidi, Anas. (2015). "Sepengertian Tanpa Sepengetahuan: Survival Strategy dan Makna Simbolik Transmisi Kelisanan (Kasus Agama Djawi-Sunda di Cigugur, Kuningan, Jawa Barat)". Disertasi Doktor Tidak Diterbitkan. Depok: Program Studi Ilmu Susastra FIPB UI [Fakultas Ilmu Pengetahuan Budaya, Universitas Indonesia]. Tersedia secara online di: http://lib. ui.ac.id/file?file=digital/2016-4/20424838-D2093Anas\%20Saidi.pdf [diakses di Tangerang, Banten, Indonesia: 9 Oktober 2017].

Saputra, Muhammad Adi. (2015). "Perkembangan Kesenian Angklung Buncis di Kecamatan Cigugur, Kabupaten Kuningan, Tahun 19802010”. Skripsi Sarjana Tidak Diterbitkan. Bandung: Jurusan Pendidikan Sejarah FPIPS UPI [Fakultas Pendidikan Ilmu Pengetahuan Sosial, Universitas Pendidikan Indonesia].

Sawunggalih, M. (2012). "Menyusur Agama DjawaSunda dari Cigugur". Tersedia secara online di: http://nusantaraislam.blogspot.com/2012/10/ menyusur-agamadjawa-sunda-dari-Cigugur. html [diakses di Tangerang, Banten, Indonesia: 9 Oktober 2017].

Sedyawati, Edi. (2007). Budaya Indonesia: Kajian Arkeologi, Seni, dan Sejarah. Jakarta: PT Raya Grafindo Persada.

Sjamsuddin, Helius. (2007). Metodologi Sejarah. Yogyakarta: Penerbit Ombak.

Soedarsono, R.M. (1986). Dampak Pariwisata terhadap Perkembangan Seni di Indonesia. Yogyakarta: ISI [Institut Seni Indonesia] Yogyakarta. 
Soedarsono, R.M. (2002). Seni Pertunjukan Indonesia di Era Globalisasi. Yogyakarta: Gadjah Mada University Press.

Soedarsono, R.M. (2003). Seni Pertunjukan dari Perspektif Politik, Sosial, dan Ekonomi. Yogyakarta: Gadjah Mada University Press.

Stake, R.E. (1995). The Art of Case Study Research. California: Sage Publications, Inc.

Subiantoro, Ignatius Herry. (2002). "Upacara Seren Taun: Sebuah Ritual Keagamaan di Cigugur, Kuningan, Jawa Barat”. Tesis Magister Tidak Diterbitkan. Yogyakarta: Program Pascasarjana UGM [Universitas Gadjah Mada].

Sutrisno, Mudji. (2005). Teori-teori Kebudayaan. Yogyakarta: Penerbit Kanisius.
Tryana, T. (2011). "Pertunjukan Angklung Buncis dalam Acara Seren Taun di Kecamatan Cigugur, Kabupaten Kuningan”. Skripsi Sarjana Tidak Diterbitkan. Bandung: Jurusan Pendidikan Seni Musik FPBS [Fakultas Pendidikan Bahasa dan Seni, Universitas Pendidikan Indonesia].

Wawancara dengan Responden A, seorang Kundang (Pelatih Angklung Buncis), di Kuningan, Jawa Barat, Indonesia, pada tanggal 19 Oktober 2014.

Wawancara dengan Responden B, Pangeran Gumirat Barana Alam, sebagai Ketua Yayasan Tri Mulya dan Wakil Ketua Adat Kundang (Pelatih Angklung Buncis), di Kuningan, Jawa Barat, Indonesia, pada tanggal 20 Oktober 2014. 
MUHAMMAD ADI SAPUTRA \& RINALDO ADI PRATAMA,

Dari Sakral Menuju Profan

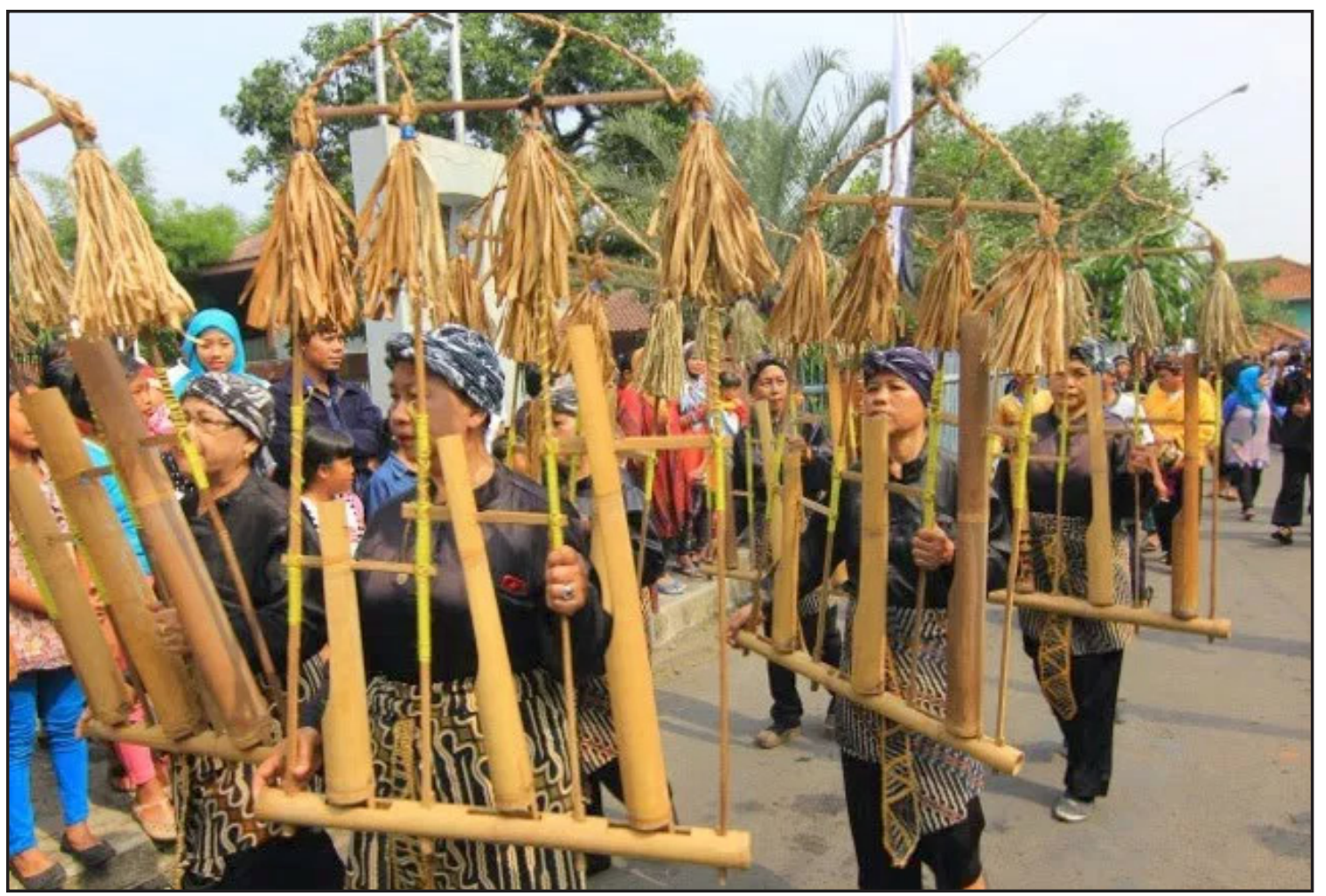

Kesenian Angklung Buncis

(Sumber: http://www.infobudaya.net, 9/10/2017)

Angklung Buncis mengalami perkembangan, khususnya pada rentang waktu 1980-2010. Perkembangan tersebut membuat Angklung Buncis mengalami perubahan yang pada awalnya berfungsi sakral dan ritual berubah menjadi sarana hiburan. Sebagai akibatnya, kesenian tersebut memiliki fungsi ganda, yakni selain memiliki fungsi sakral juga fungsi hiburan atau profan. 